\title{
Is the US Method of Challenging China's IP-related Practices Legally Tenable from an International Legal Perspective?
}

Yang $\mathrm{Yu}^{*}$

The US initiated a Section 301 investigation against China in 2017. Such a unilateral investigation has run counter to the explicit commitments in the Statement of Administrative Action. Even the basically reasonable 'four corners' defense can neither apply nor justify this investigation. Consequently, especially based on the Panel's additional emphasis, the conditional international legality confirmed by the Panel of DS152 case in the WTO should be untenable in this latest specific context. By reutilizing this globally aversive tool, the United States could possibly prove itself to be an unreliable partner and this would unavoidably incur severe reputational costs and other potential harms to itself. Furthermore, this might, to some degree, undermine or even undo the advances achieved in more than twenty years of international rule of law in world trade after the establishment of the WTO. All in all, only mutually beneficial solutions are most desirable, effective and sustainable for both China and the US.

\section{Keywords}

Section 301, IPR, WTO Dispute Settlement, China-US Trade War, International Law

\footnotetext{
* Associate Professor at WTO Chair Institute-China (WTO Chairs Programme) of Shanghai University of International Business and Economics; Research Fellow in Shanghai Center for Global Trade and Economic Governance. Ph.D. (Fudan). ORCID: http://orcid.org/0000-0001-5467-6397. This paper is supported by Shanghai Philosophical and Social Science General Reserch Project (No. 2018BFX020) and WTO Chairs Programme. The author may be contacted at: wtoyuyang@suibe.edu.cn /Address: Rm. 412, Multifunctional Building, 620 Gubei Road, Shanghai 200336 P.R. China. DOI: http://dx.doi.org/10.14330/jeail.2018.11.2.08
} 


\section{Introduction}

'Section 301'1 became known to China in the early 1990s. ${ }^{2}$ Since August 2017, this legal watershed developed into a major point of contention again in China by the newly initiated Section 301 investigation $^{3}$ against China. China became aware of 'Special 301' in 1991 when it was one of the first three countries to be named a Priority Foreign Country. After lengthy negotiations, China and the US agreed upon in a comprehensive Memorandum of Understanding ("MOU"), which was signed on January 17, 1992, just hours before the implementation of US retaliatory measures. ${ }^{4}$

The pertinent Section 301 investigation against China was initiated in 2017 over intellectual property ("IP") issues and concerns. This investigation is unique especially from the perspective of international law. Generally speaking, both China and the US are facing a crucial turning point concerning bilateral trade relations, and even the overall bilateral relationship. To some extent, this unilateral investigation would challenge the long-term sustainable development of international trade law since the end of World War II. ${ }^{5}$

119 U.S.C. \$2411. Especially in the context of WTO dispute settlement, 'Section 301' may represent a joint name of a series of sections from Section 301 to Section 310. See DS152: United States-Sections 301-310 of the Trade Act 1974,' available at https://www.wto.org/english/tratop_e/dispu_e/cases_e/ds152_e.htm; DS543: United States-Tariff Measures on Certain Goods from China, available at https:/www.wto.org/english/tratop_e/dispu_e/cases_e/ds543_ e.htm (all last visited on Oct. 24, 2018).

2 E.g., 'Section 301 ' is the 'big stick' that the USTR frequently waves to threaten and make submissive its trade adversaries, and fully reflects the US economic hegemony in international trade.' See An Chen, The Three Big Rounds of U.S. Unilateralism versus WTO Multilateralism during the Last Decade: A Combined Analysis of the Great 1994 Sovereignty Debate, Section 301 Disputes (1998-2000), and Section 201 Disputes (2002-Present), 17 Temp. INT'L \& Comp. L. J. 425-6 (2003).

3 See President Trump Takes Action on Intellectual Property Rights, White House News, Aug. 14, 2017, available at https:/www.whitehouse.gov/articles/president-trump-takes-action-intellectual-property-rights. See also Presidential Memorandum for the United States Trade Representative, White House News, Aug. 14, 2017, available at https:// www.whitehouse.gov/presidential-actions/presidential-memorandum-united-states-trade-representative (all last visited on Oct. 24, 2018).

4 K. Newby, The Effectiveness of Special 301 in Creating Long Term Copyright Protection for U.S. Companies Overseas, 21 Syracuse J. Int'L L. \& Com. 42 (1995). For details on Sino-US IP conflicts in the 1990s, see P. Yu, Piracy, Prejudice, And Perspectives: An Attempt to Use Shakespeare To Reconfigure the U.S.-China Intellectual Property Debate, 19 B.U. InT'L L.J. 133-6 (2001). As regard China-related origin of 'Special 301,' the US has criticized China's inadequate protection of IPRs. The criticism increased after 1988 when the OTCA came into force, which created a special provision on IP in Section 301. See Qiao Dexi, A Survey of Intellectual Property Issues in China-U.S. Trade Negotiations under the Special 301 Provisions, 2 PAC. Rıм. L. \& PoL'y J. 265 (1993).

5 Such unilateral institutional element even originated from the brewing of Trade Act of 1974 based upon doubts about the reliablity of the GATT dispute settlement mechanism. A House bill states:

Your committee is particularly concerned that the decisionmaking process in the GATT is such as to make it impossible in practice for the United States to obtain a determination with respect to certain practices of our trading 
The primary purpose of this research is to analyze the legal tenability of America's Methods of Challenging China's IP-related Practices in terms of a Section 301 investigation in 2017-2018 in order to achieve feasible and mutually beneficial solutions to such trade conflicts. This paper is composed of five sections including Introduction and Conclusion. Part two will briefly introduce the initiation of the Section 301 investigation in August 2017. Part three will analyze the conditional international legality of Section 301 and its enforcement from the perspective of WTO case law. Part four will analyze the legally questionable unilateralism in such an unprecedented and unusual combination of a Section 301 investigation and a WTO complaint both against China in 2018.

\title{
II. The Section 301 Investigation against China in 2017
}

\section{A. A brief Introduction to Section 301}

\section{Section 301}

Section 301 was initially enacted in the Trade Act of $1974^{6}$ and amended in the 1980 s and the 1990s. Palmeter briefly generalized:

\begin{abstract}
Section 301 of the 1974 Act probably is unique among U.S. trade laws in that its goal is not the restriction of imports, but the expansion of exports. Its immediate antecedent was section 252 of the Trade Expansion Act of 1962, although its roots may be traced at least as far back as 1794 . $^{7}$
\end{abstract}

Since its inception, the underlying aim of this section was to obtain as much bargaining leverage for further negotiations instead of actually imposing unilateral trade

partners which appear to be clear violations of the GATT....The committee believes that it is essential for the United States to be able to act unilaterally in any situation where it is unable to obtain redress through the GATT against practices which discriminate against or unreasonably impair U.S. export opportunities.

See H.R. REP. No. 93-571, 93d Cong., 1st Sess. 66 (1973), at 66-7, recited from R. Hudec, Retaliation against "Unreasonable" Foreign Trade Practices: The New Section 301 and GATT Nullification and Impairment, 59 MinN. L. Rev. 461 (n. 147) (1975).

6 Trade Act of 1974, Pub. L. No. 93-618 (Jan. 3, 1975), available at https://www.congress.gov/bill/93rd-congress/housebill/10710/committees (last visited on Oct. 24, 2018).

7 N. Palmeter, The Trade and Tariff Act of 1984: From the Customs Treatment of Manhole Covers to the Return of Goods from Outer Space, 11 Syracuse J. InT'L L. \& Com. 519 (1984). 
sanctions. ${ }^{8}$ Accordingly, this kind of aggressive unilateral trade sanction mechanism triggered vehement negative responses from America's trading partners. ${ }^{9}$ Generally, "unlike the more covert Article XXIII doctrine, Section 301 is openly and unashamedly punitive in purpose." ${ }^{10}$ It is a legal mechanism enacted in trade law directly against:

An act, policy, or practice of a foreign country-(i) violates, or is inconsistent with, the provisions of, or otherwise denies benefits to the United States under, any trade agreement, or (ii) is unjustifiable and burdens or restricts United States commerce ${ }^{11}$;

An act, policy, or practice of a foreign country is unreasonable or discriminatory and burdens or restricts United States commerce. ${ }^{12}$

'Unreasonableness,' inter alia, may be the most disputed and 'powerful' element in this legal mechanism. ${ }^{13}$ In addition, the whole enforcement mechanism of Section 301 tends to be at least partially political in nature, ${ }^{14}$ particularly in light of some amendments for enhancing presidential authority in such investigations. ${ }^{15}$

8 As observed, e.g., "the majority of $\S 301$ investigations were terminated without Presidential retaliation because bilateral or multilateral negotiations usually prompted improvements in the allegedly "unfair" practices. Thus, the $\S$ 301 proceeding usually encouraged negotiations with foreign governments and often led to mutually acceptable trade dispute resolutions, rather than Presidential action." See F. Nara, A Shift toward Protectionism under 301 of the 1974 Trade Act: Problems of Unilateral Trade Retaliation under International Law, 19 HoFstRa L. Rev. 235 (1990).

9 E.g., "of all the US international trade statutes, perhaps none elicits greater international condemnation than Section 301." See A. Sykes, "Mandatory" Retaliation for Breach of Trade Agreements: Some Thoughts on the Strategic Design of Section 301, 8 B.U. INT'L L. J. 301 (1990).

10 Hudec, supra note 5, at 521.

1119 U.S.C. $\$ 2411(\mathrm{a})(1)(\mathrm{B})$.

12 Id. $\$ 2411(\mathrm{~b})(1)$.

13 "Section 301's authorization of action against 'unreasonable' foreign government practices may be the statute's most powerful weapon for achieving the elimination of 'unfair' distortionary commercial policies." See P. Hansen, Defining Unreasonableness in International Trade: Section 301 of the Trade Act of 1974, 96 Y ALE L. J. 1133 (1987).

14 As generalized, "historically, decisions to initiate section 301 actions were based not only upon economics, but in numerous instances, upon political expediency. For example, the first three investigations initiated by the President under section 301 were based on political considerations." See D. Pedley, A Definition for "Unreasonable" in Section 301 of the Trade Act of 1974: A Consideration of the United States - Thailand Tobacco Dispute, 5 Emory InT'L L. REv. 289-90 (1991). As similarly stated, "the provision was considered extremely political because the ultimate power to retaliate was conferred upon the President alone. Thus, the President weighed the merits of $\S 301$ retaliation against other factors of international relations." See Nara, supra note 8, at 234.

15 Some research partially focuses on this president-related facet, or even including the president-congress relationship in terms of the enforcement of Section 301. See M. Echols, Section 301: Access to Foreign Markets from an Agricultural Perspective, 6 InT'L TRAde L. J. 16 (1980). "Another historical first was the President's direction to the Trade Representative to initiate investigations under section 302 on his own motion. On September 16, 1985, the Trade Representative 'self-initiated' three investigations..." See J. Bello \& A. Holmer, Significant Recent Developments in Section 301 Unfair Trade Cases, 21 INT’L Law. 219 (1987). "The statute has also attracted attention because of President 


\section{Special 301}

'Special $301{ }^{16}$ was enacted to supplement and strengthen the enforcement of Section 301 specifically for adequately and effectively protecting the US and its commercial interests ${ }^{17}$ in IP matters abroad. In short, this mechanism is embodied as a specific structure of three level severity of defects in terms of IP protection.

If certain countries can be identified as priority foreign countries on the highest level, the US deems them to have the most onerous or egregious acts, policies, or practices that deny either adequate and effective IP rights, or fair and equitable market access to the American people relying upon IP protection, etc. ${ }^{18}$ Once a country is identified as a priority foreign country, an IP-based Section 301 investigation would be subsequently processed. ${ }^{19}$ The middle level countries with less severe IP-related deficiencies are identified for placement on the Priority Watch List. ${ }^{20}$ The lowest level countries with relatively less severe IP-related deficiencies are identified on the Watch List. ${ }^{21}$ Although a country on the Priority Watch List or Watch List will not face Section 301 investigation in the short term, they face the unsavory prospect of being investigated at any time. ${ }^{22}$ Once additionally identified as a priority foreign country, one may face the same situation as countries identified as priority foreign countries in the annually released Special 301 report.

In case of an investigation against a priority foreign country ceases, particularly, the United States Trade Representative ("USTR") can choose one or a few types of specific trade sanctions, such as authority to 'suspend, withdraw, or prevent the

Reagan's unprecedented decision in September 1985 to begin initiating section 301 investigations on his own motion rather than waiting for a private petitioner to trigger action under the statute." See Hansen, supra note 13, at 1124. "The United States Congress has generally regarded itself as the final (and only true) protector of reciprocity in foreign trade commitments. The Congress harbors a lingering suspicion that the Executive Branch can be persuaded on occasion to sacrifice United States economic interests for the sake of friendly political relations." See Hudec, supra note 5, at 510.

1619 U.S.C. $\S 2242$.

17 For instance, "absent worldwide respect for the protection of intellectual property rights, American companies are unable not only to obtain the rewards for their inventions-which translate into sales, profits, and employment-but also to finance research and development for the next generations of their products." See D. Wilson, A Trade Policy Goal for the 1990s: Improving the Adequacy and Effectiveness of Intellectual Property Protection in Foreign Countries, 1 Global Bus. \& Dev. L. J. 422 (1988).

1819 U.S.C. $\$ 2242(\mathrm{~b})(1)$.

19 Id. $\$ 2412(\mathrm{~b})(2)(\mathrm{A})$.

$20 \quad$ Id. $\$ 2242(\mathrm{~g})$.

21 This level was not enacted in the provision of Special 301, but emerged as a formal practice since the first Special 301 report released in 1989. See '1989 Special 301 Report', at 1, available at https://ustr.gov/issue-areas/intellectualproperty/special-301/previous-special-301-reports (last visited on Oct. 24, 2018).

2219 U.S.C. $\$ 2242(\mathrm{c})(1)(B)$. It provides: "The Trade Representative may at any time - ... (B) identify any foreign country as a priority foreign country under this section, if information available to the Trade Representative indicates that such action is appropriate..." 
application of, benefits of trade agreement concessions' or 'impose duties or other import restrictions,' etc. ${ }^{23}$ Such a legal mechanism would trigger severe concerns among its trading partners and incur questioning and even criticism in academia. ${ }^{24}$

\section{B. The 'Unexpected' and 'Unusual' Initiation of Section 301 Investigation in 2017}

China has been on the Priority Watch List for more than 10 years by the US' unilateral identification ${ }^{25}$ because of insufficient IP protection. In this course, nonetheless, annual bilateral negotiations in the US-China Joint Commission on Commerce and Trade ("JCCT") ${ }^{26}$ and the US-China Comprehensive Economic Dialogue ("S\&ED") ${ }^{27}$ were going well focusing on commerce and trade questions. When IP-related conflicts could not be effectively solved via bilateral talks or formal negotiations, the WTO dispute settlement system would be applied to resolve such disputes. ${ }^{28}$ This clearly indicates that such a unilateral threat of trade sanctions against a WTO member concerning IP issues is unnecessary and abnormal under the effectively operating WTO dispute settlement mechanism.

The US had not instituted Section 301 investigation up until 2017. ${ }^{29}$ To some

23 Id. $\$ 2411(\mathrm{c})$.

24 For instance, "the frustration expressed by the rest of the world at the sight of the United States using unilateral Section 301 measures to assure greater protection for only its intellectual property rights, even after signing TRIPS, seems understandable and well-founded." See L. Monten, The Inconsistency between Section 301 and TRIPS: Counterproductive with Respect to the Future of International Protection of Intellectual Property Rights, 9 MARQ. InTELl. Prop. L. Rev. 421 (2005). In addition to such concerns sporadically expressed in some articles, there also exist other articles wholly cast doubt on 'Special 301' mechanism or its specific use in some contexts. See S. Zhou, Challenging the Use of Special 301 against Measures Promoting Access to Medicines: Options under the WTO Agreements, 19 J. INT'L ECON. L. 51-86 (2016).

25 USTR, Annual 'Special 301' reports (1989-2018), available at https://ustr.gov/issue-areas/intellectual-property/ Special-301 (last visited on Oct. 24, 2018).

26 See U.S. Fact Sheet for the 27th U.S.-China Joint Commission on Commerce and Trade, available at https:/ustr.gov/about-us/ policy-offices/press-office/fact-sheets/2016/november/us-fact-sheet-27th-us-china-joint (last visited on Oct. 24, 2018).

27 See 2016 U.S.-China Strategic and Economic Dialogue U.S. Fact Sheet - Economic Track, available at https://www. treasury.gov/press-center/press-releases/Pages/j10485.aspx (last visited on Oct. 24, 2018).

28 "On 10 April 2007, the United States requested consultations with China concerning certain measures pertaining to the protection and enforcement of intellectual property rights in China." See Panel Report, China-Measures Affecting the Protection and Enforcement of Intellectual Property Rights, WTO Doc. WT/DS362/R (adopted Jan. 26, 2009), available at https:/www.wto.org/english/tratop_e/dispu_e/cases_e/ds362_e.htm\# (last visited on Oct. 24, 2018). Such an IP-related WTO complaint finally led to a basically acceptable and satisfactory result to both sides. This case and the corresponding adjudication undoubtedly proved that the WTO dispute settlement mechanism should be deemed as adequately competent and effective for resolving such kind of IP-related trade disputes between the US and China.

29 "The U.S. Trade Representative self-initiated a Section 301 investigation into whether Chinese policies, acts, and practices related to technology transfer, licensing, and intellectual property are unreasonable or discriminatory. This is the first use of Section 301 since 2001." See President Donald J. Trump: Year One of Making America Great Again, White House News, Dec. 22, 2017, available at https:/www.whitehouse.gov/briefings-statements/president-donald-j- 
degree, Section 301 investigation of 2017 is an 'unexpected' and 'unusual' measure for not only China, but also the international community.

On August 14, 2017, President Donald Trump signed a Presidential Memorandum directing "the USTR Robert Lighthizer to determine, consistent with section 302(b) of the Trade Act of 1974 (19 U.S.C. 2412(b)), whether to investigate any of the acts, policies, or practices of China that may be unreasonable or discriminatory and that may be harming American intellectual property, innovation, and technology." ${ }^{30}$ Soon after this memorandum, on August 18, 2017, "the US Trade Representative Robert Lighthizer formally initiated an investigation of China under Section 301 of the Trade Act of 1974." ${ }^{31}$ President Trump has a different approach from his predecessors who tried to resolve trade-related disputes through direct bilateral negotiations or the WTO dispute settlement. Briefly, there were two key elements stressed by the USTR in this Section 301 investigation. One is technology transfer, while the other is IP theft, both in the field of IP. ${ }^{32}$ Particularly, as stated in that Presidential Memorandum, the Sino-US 'trade deficit' ${ }^{33}$ was clearly refocused to emphasize a link to IP-related issues.

\section{Conditional Legality of Section 301 and Its Enforcement from the Perspective of Treaty Interpretation}

The legality of Section 301 and its enforcement was debated in the international

trump-year-one-making-america-great (last visited on Oct. 24, 2018).

30

Supra note 3.

31 See USTR Announces Initiation of Section 301 Investigation of China, Aug. 18, 2017, available at https://ustr.gov/ about-us/policy-offices/press-office/press-releases/2017/august/ustr-announces-initiation-section (last visited on Oct. 24, 2018).

32 See Notice of initiation of investigation; hearing; and request for comments, 82 FR 40213, at 4-5, available at https:// www.gpo.gov/fdsys/pkg/FR-2017-08-24/html/2017-17931.htm (last visited on Oct. 24, 2018).

33 It seems that fighting against Sino-US 'trade deficit' is another crucial purpose of this investigation. With regard to similar circumstances in previous Section 301 investigation, "perhaps most importantly, section 301 has a potentially profound economic significance. The United States desperately needs to improve its balance of trade position through increased exports of goods and services." See B. Fisher \& R. Steinhardt, Section 301 of the trade act of 1974: protection for U.S. Exporters of goods, services, and capital, 14 L. \& PoL'Y INT'L Bus. 581 (1982). Nevertheless, as illuminated by existing research, Section 301 may not be the right tool for addressing issues regarding 'trade deficit.' For example, "Section 301 will not fix the trade deficit. The trade deficit arises from broader macroeconomic factors that have a very limited relationship to U.S. trade policy or unfair trade practices." See W. Maruyama, Section 301 and the Appearance of Unilateralism, 11 Мich. J. InT’L L. 400 (1990). "Whether Section 301 exists or not, the answer to our trade problems must lie in macroeconomic policy and not punitive trade measures." See R. Diamond, Changes in the Game: Understanding the Relationship between Section 301 and US Trade Strategies, 8 B.U. InT'L L. J. 351 (1990). 
community until December 22, 1999 when a WTO Panel Report ${ }^{34}$ was circulated. From that point forward, the US stopped imposing or threatening to impose unilateral trade sanctions through the Section 301 mechanism. In 2017, however, the US adopted the unusual and unprecedented combination of both Section 301 sanction and WTO complaint against China. It is thus necessary to review the conditional legality of Section 301 and its enforcement thoroughly from the perspective of treaty interpretation. In particular, such a combination of Section 301 sanction and the WTO complain should be fully anatomized by legal reasoning contained in the 1999 WTO Panel Report.

\section{A. Unilateral Enforcement of Section 301 in IP Domain before 1999}

Special 301 is an example of unilateral enforcement which caused widespread international concerns, especially among developing countries during the long process of the Uruguay Round of negotiations. Actually, Special 301 was one of the highly topical issues in these negotiations. For instance, an official note taken by the secretariat of the Negotiating Group on Trade-Related Aspects of Intellectual Property Rights including Trade in Counterfeit Goods in a meeting in June 1991 provides:

Referring to the Special 301 provisions of the existing United States Trade Law, which empower the United States Trade Representative to take retaliatory actions against "offending" countries, a participant expressed his delegation's grave concern about this type of unilateral action and their impact on his country's position in these negotiations on TRIPS. In his delegation's view the nomination of "priority foreign countries" was in itself a violation of the commitments under the Punta del Este Declaration on standstill and rollback, which required participants not to take any measures that would improve their negotiating positions. ${ }^{35}$

In this regard, other negotiating parties, particularly developing countries, have

DS 152, supra note 1

https://www.wto.org/english/tratop_e/trips_e/trips_e.htm\#NegHist (last visited on Oct. 24, 2018). In fact, during the negotiation process of the Uruguay Round, Section 301 also played an important role of accelerating the achievement of the intended goals. For example, Ambassador Hills stated: "Bilateral negotiations and actions we have taken under our domestic legal procedures, including section 301, are fully complementary to our Uruguay Round objectives." See J. Bello \& A. Holmer, "Special 301": Its Requirements, Implementation, and Significance, 13 FordHAm InT'L L. J. 273 (1989-90). "The U.S. basis for the heavy use of the statute were to push for increased compliance with GATT rules and to get other countries to agree that new areas, particularly intellectual property rights and trade in services, should be part of the agenda of the Uruguay Round negotiations." See C. Taylor, Impossible Cases: Lessons from the First Decade of WTO Dispute Settlement, 28 U. PA. J. InT'L Econ. L. 423 (2007). 
a variety of incentives for accepting the Agreement on Trade-Related Aspects of Intellectual Property Rights ("TRIPs") mainly proposed by the US. In addition to exchanging trade benefits for other sectors, the acceptance of TRIPs also seemed to be conducive for developing countries to substantially reduce the threat of Special 301 and the related unilateral trade sanctions. ${ }^{36}$

Also, the US was interested in satisfactorily solving IP-related disputes through the Uruguay Round negotiations. Firstly, if achieving the goal of the desirable TRIPs ${ }^{37}$ with a minimum standard of protection for a variety of IP rights, the US could efficiently establish a satisfactory level of IP protection among all the contracting parties instead of conducting a multitude of parallel bilateral negotiations with the threat of Section 301 sanctions.

Secondly, theoretically, the new dispute settlement mechanism after the Uruguay Round would help the US unprecedentedly in solving trade-related IP disputes through a multilateral legal framework without further suffering from reputational costs especially in terms of being accused of threatening developing countries with Section 301 sanctions. $^{38}$

\section{B. Actual or Potential Illegality of Section 301 and Its Enforcement}

Since 1974, commentaries have been made frequently on Section 301 enforcement and amendment, focusing on the question of legality. ${ }^{39}$ Such ideas particularly

36 "It is equally conceivable that the filing of section 301 petitions will accelerate the adoption of multilateral rules in order to avoid bilateral ad hoc solutions or unilateral retaliation." See Fisher et al., supra note 33, at 664. "So long as the Administration can refrain from taking harsher action under Special 301 for the duration of the Uruguay Round negotiations, Special 301 is unlikely to damage those negotiations and thus unlikely to harm the prospects for achieving a satisfactory multilateral GATT agreement on protecting intellectual property." See Bello et al., supra note 35, at 275.

37 Extending the GATT to intellectual property issues was closely linked to the future enforcement of Section 301. As argued, "if the United States succeeds in extending the GATT to new areas (such as services, investment and intellectual property) and substantially improving GATT discipline in traditional areas (such as agriculture and dispute settlement), then the 1988 Trade Act will be less important in the long term." See J. Bello \& A. Holmer, The Heart of the 1988 Trade Act: A Legislative History of the Amendments to Section 301, 25 STAN. J. InT'L L. 44 (1988).

38 There exist similar viewpoints on this aspect. For instance, "if the Uruguay Round does produce an effective procedure for third-party dispute resolution, the need for unilateral threat strategies to protect U.S. interests will diminish greatly. The continued existence of the statutory authority for unilateral action may in fact become counterproductive, as such actions may be perceived as facilitating opportunism while serving no constructive function." See A. Sykes, Constructive Unilateral Threats in International Commercial Relations: The Limited Case for Section 301, 23 L. \& PoL'y INT'L Bus. 290 (1992). "While the Uruguay Round was ongoing, U.S. negotiators could argue that the weaknesses in the international trading system left no alternative for the United States but to turn to unilateralism. However, now that most of the reforms to the system demanded by the United States have been accepted in the WTO, including a new TRIPS agreement and a strengthened DSU, these claims will no longer be credible." See J. Gero \& K. Lannan, Trade and Innovation: Unilateralism v. Multilateralism, 21 CAN.-U.S. L. J. 97 (1995).

39 In addition to viewpoints squarely questioning or criticizing the international legality of Section 301 and its enforcement, there are also some views questioning other aspects of this Section. "Even as a partial solution to our trade 
expressed the conditional or potential conflicts between Section 301 and GATT (or DSU/TRIPS). Some representative views in this category are listed chronologically in Table 1.

Table 1: Conflicts between Section 301 and GATT/DSU/TRIPS

\begin{tabular}{|c|l|}
\hline Year & \multicolumn{1}{c|}{ Type of Conflicts } \\
\hline 1975 & $\begin{array}{l}\text { The third type of section 301 retaliation would be an action based solely and } \\
\text { squarely on the declared 'unreasonableness' of an otherwise legal trade barrier. } \\
\text { This is the type of action that most congressmen probably had in mind when } \\
\text { they considered section 301. It is, of course, the most questionable form of } \\
\text { retaliation by GATT standards. }\end{array}$ \\
\hline 1980 & $\begin{array}{l}\text { The President rarely used his statutory authority to retaliate against practices } \\
\text { deemed unfair. The use of that authority raised major issue concerning the } \\
\text { U.S. government's compliance with international rules regarding acceptable } \\
\text { procedures for dispute settlement and most-favored-nation treatment. }\end{array}$ \\
\hline 1982 & $\begin{array}{l}\text { The section 301 process is perhaps the most difficult of possible roads to relief ... } \\
\text { The heart of the retaliation issue is not whether or not the President should have } \\
\text { authority to retaliate, but whether or not his action can be squared with U.S. } \\
\text { obligations under international agreements. }\end{array}$ \\
\hline 1987 & $\begin{array}{l}\text { There is also a potential conflict between section 301 and the GATT principle } \\
\text { that trade should be conducted on a basis of nondiscrimination. In this regard, } \\
\text { the most-favored-nation (MN) provision in article I of GATT is of particular } \\
\text { importance. In general, this provision requires that each nation with MFN status } \\
\text { receive, with certain exceptions, at least as favorable treatment for its exports as } \\
\text { any other nation. The potential conflict of this principle with section 301 occurs } \\
\text { when retaliatory action against a United States trading partner pursuant to } \\
\text { section 301 destroys MFN treatment for that nation. }{ }^{43}\end{array}$ \\
\hline $\begin{array}{l}\text { Theoretically, under the GATT, a party may not take unilateral action in most } \\
\text { cases until the GATT process is concluded and the GATT authorizes action. } \\
\text { Therefore, an eighteen month section 301 deadline means a case could be pulled } \\
\text { from the GATT and, in light of the new mandatory retaliation provision, the } \\
\text { United States might take unilateral action in violation of the GATT. }\end{array}$ \\
\hline
\end{tabular}

problems, Section 301 raises many questions. Does it enhance national welfare or is it simply a potential grabbag for special interest groups seeking to obtain protection from foreign competition?' See Diamond, supra note 33, at 351.

40 Hudec, supra note 5, at 525.

41 Echols, supra note 15, at 21.

42 R. Gadbaw, Reciprocity and Its Implications for U.S. Trade Policy, 14 L. \& PoL'y InT'L Bus. 738 (1982).

43 K. Thatcher, Section 301 of the Trade Act of 1974: Its Utility against Alleged Unfair Trade Practices by the Japanese Government, 81 Nw. U. L. Rev. 517 (1987).

44 S. Phillips, The New Section 301 of the Omnibus Trade and Competitiveness Act of 1988: Trade Wars or Open Markets?, 22 VAND. J. TRANSNAT'L L. 517 (1989). 


\begin{tabular}{|c|c|}
\hline 1990 & $\begin{array}{l}\text { It is fair to say that at least the basic principles of GATT have evolved into } \\
\text { customary international law. Section 301, therefore, arguably violates customary } \\
\text { international law, which the Supreme Court has determined binds the United } \\
\text { States. }\end{array}$ \\
\hline 1991 & $\begin{array}{l}\text { U.S. unilateralism in defining and retaliating against "unfair" foreign trade } \\
\text { practices is widely regarded as entirely inconsistent with the multilateral spirit } \\
\text { of GATT and, especially, as inconsistent with the Uruguay Round effort to } \\
\text { enhance GATT's effectiveness... U.S. retaliation is all the more troubling when, } \\
\text { as in the case of its attack on Brazil's patent law, the United States is attacking } \\
\text { practices that are perfectly lawful under international law and that have been } \\
\text { determined to be unfair solely on the basis of a U.S. ipse dixit... In those cases, the } \\
\text { use of Section } 301 \text { becomes a raw exercise of power. It aims at opening markets } \\
\text { not in pursuit of law, not through multilateral negotiation-indeed, not through } \\
\text { negotiation at all, but through threat and coercion. }\end{array}$ \\
\hline 1992 & $\begin{array}{l}\text { Unilateral action, such as that which can be taken under Special 301, is contrary } \\
\text { to the letter and spirit of the GATT which provides a method of dispute } \\
\text { resolution in Article XXIII. If unilateral action is taken frequently, the GATT } \\
\text { system would soon collapse. }\end{array}$ \\
\hline 1995 & $\begin{array}{l}\text { The DSU also reduces the credibility of the threat of section } 301 \text { unilateral } \\
\text { retaliation, since such retaliation is likely to violate the WTO provisions. }\end{array}$ \\
\hline 1995 & $\begin{array}{l}\text { It seems unlikely that the United States will take unilateral action under Section } \\
301 \text { against a GATT } 1994 \text { contracting party measure that falls within the areas } \\
\text { covered by WTO agreements without due recourse to the DSU rules and } \\
\text { procedures. In doing so, the United States would be taking an action inconsistent } \\
\text { with the DSU rules and procedures and therefore, putting itself in open violation } \\
\text { of GATT obligations. }\end{array}$ \\
\hline 1995 & $\begin{array}{l}\text { Now that the World Trade Organization Agreement on Trade-Related } \\
\text { Aspects of Intellectual Property Rights (TRIPs) has become effective, it may be } \\
\text { expected that, for WTO members, the dispute settlement provisions of TRIPs as } \\
\text { incorporated into Section 301, will be used when the United States accuses WTO } \\
\text { member nations of intellectual property violations. }\end{array}$ \\
\hline 1997 & $\begin{array}{l}\text { Any unilateral action by the United States in that case would violate Article XXIII } \\
\text { of the DSU. By taking such action, the United States would expose itself to a } \\
\text { WTO case being filed against it by the Section } 301 \text { target country. }\end{array}$ \\
\hline
\end{tabular}

45 Nara, supra note 8 , at 255.

46 J. Carlson, The United States Commitment to International Trade Law: The Role of a Declining Hegemon, 1 Transnat'L L. \& Contemp. Probs. 110 (1991).

47 Mitsuo Matsushita, A Japanese Perspective on Intellectual Property Rights and the GATT, 1992 CoLum. Bus. L. REv. 90(1992).

48 Gero, supra note 38 , at 95.

49 S. Puente, Section 301 and the New WTO Dispute Settlement Understanding, 2 ILSA J. INT'L \& COMP. L. 228 (1995).

50 D. Gantz, A Post-Uruguay Round Introduction to International Trade Law in The United States, 12 Ariz. J. InT'L \& Comp. L. 119 (1995).

51 C. Taylor, The Limits of Economic Power: Section 301 and the World Trade Organization Dispute Settlement System, 30 VAND. J. TRanSNAT'L L. 272 (1997). 


\begin{tabular}{|l|l|}
\hline 1998 & $\begin{array}{l}\text { By agreeing to TRIPs, other countries were in effect attempting to ensure that } \\
\text { the United States would be precluded from implementing such methods of } \\
\text { unilateral coercion in the future. The implication is that the use of unilateral } \\
\text { coercion to force intellectual property protection in the face of TRIPs violates the } \\
\text { entire purpose of the TRIPs Agreement. }\end{array}$ \\
\hline 2016 & $\begin{array}{l}\text {-.the article examines whether there are substantive limitations on intellectual } \\
\text { property protections under TRIPS which could be used to challenge the validity } \\
\text { of Special 301. It concludes that some, but not all, aspects of Special } 301 \text { may be } \\
\text { inconsistent with WTO obligations. }\end{array}$ \\
\hline
\end{tabular}

Compiled by the author.

Such representative viewpoints exemplified the long-lasting doubts and controversies surrounding the legality of Section 301. Furthermore, as listed above, such doubts and controversies were not alleviated by establishing the WTO in 1995. Instead, international discontent with Section 301 even reached a crescendo in terms of a WTO complaint initiated by the European Communities in $1998^{54}$

\section{Legal Analysis of the WTO Panel Report concerning the Conditional Legality of Section 301 and Its Enforcement}

In the report, the WTO panel highlighted the 'conditional' legality of Section 301 and its enforcement mechanism as follows. Firstly, the WTO panel stated:

[i]n evaluating the conformity of Sections 301-310 with the relevant WTO provisions we must, thus, be cognizant of this multi-layered character of the national law under consideration which includes statutory language as well as other institutional and administrative elements. ${ }^{55}$

Obviously, the key purpose of this statement is to stress the necessity of evaluating all the related legal elements in addition to the Sections 301-310 per se. This integral analysis is reasonable.

Secondly, based on this overall evaluation approach, the panel made a relatively specific example in terms of generally exemplifying two opposite situations below, in order to emphasize the importance of the role and function of domestic

52 R. Pechman, Seeking Multilateral Protection for Intellectual Property: The United States TRIPs over Special 301, 7 Minn. J. Global Trade 202 (1998).

53 Zhou, supra note 24, at 51.

54 DS152, supra note 1.

55 Id. $₫ 7.26$. 
administrative elements under certain circumstances. For example, even though the statutory language granting specific powers to a government agency may be prima facie consistent with the WTO rules, the responsible agency, within the discretion given to it, may adopt internal criteria or administrative procedures inconsistent with the WTO obligations which would lead to violation of the overall law. The opposite may be equally true. Although the statutory language as such may be prima facie inconsistent, such inconsistency may be lawfully removed by examining other administrative or institutional elements of the same law. ${ }^{56}$

Thirdly, after examining the statutory language of Section 304 per se in detail, the panel reached a preliminary conclusion of a prima facie violation of Article 23.2(a) by stating:

pursuant to our examination of text, context and object-and-purpose of Article 23.2(a) we find, at least prima facie, that the statutory language of Section 304 precludes compliance with Article 23.2(a). This is so because of the nature of the obligations under Article 23. Under Article 23 the US promised to have recourse to and abide by the DSU rules and procedures, specifically not to resort to unilateral measures referred to in Article 23.2(a). In Section 304, in contrast, the US statutorily reserves the right to do so. In our view, because of that, the statutory language of Section 304 constitutes a prima facie violation of Article 23.2(a). ${ }^{57}$

Fourthly, although the panel found a prima facie violation, the final conclusion of actual violation had not been confirmed yet because all the related elements should be assessed in unison. The panel placed particular emphasis on examining the limitation on the USTR's discretion under Section 304 contained in the US Statement of Administrative Action ("SAA"). The panel especially focused on one of the commitments approved by the US Congress. The panel quoted:

Although it will enhance the effectiveness of section 301, the DSU does not require any significant change in section 301 for investigations that involve an alleged violation of a Uruguay Round agreement or the impairment of U.S. benefits under such an agreement. In such cases, the Trade Representative will:

- base any section 301 determination that there has been a violation or denial of U.S. rights under the relevant agreement on the panel or Appellate Body findings adopted by the DSB; $\ldots{ }^{58}$ 
Essentially based on the fact that "the US explicitly, officially, repeatedly and unconditionally confirmed the commitment expressed in the SAA," 59 the panel found that "Section 304 is not inconsistent with US obligations under Article 23.2(a) of the DSU." This step is the concrete embodiment of the holistic analytical logic stressed in the above-mentioned second step in the context of this specific case.

Finally, after making such specific findings in this case, the panel particularly emphasized the conditionality of the final conclusion. It explicitly stated that this finding is not unconditionally tenable under any circumstances as follows.

Should the undertakings articulated in the SAA and confirmed and amplified by the US to this Panel be repudiated or in any other way removed by the US Administration or another branch of the US Government, this finding of conformity would no longer be warranted. ${ }^{61}$

In essence, this means, the key and sole element which ensure the 'conditional' legality of Section 301 and its overall enforcement mechanism is the unequivocal and formal commitments made in the SAA listed above. Once the US reneges on its international promise embodied in the formal commitments to the SAA, such conditional legality will not exist any longer.

\section{The Unilateralism in the Combination of Section 301 Sanctions and the WTO Complaint against China in 2018}

\section{A. Combination of Section 301 Sanctions and the WTO Complaint against China in 2018}

After approximately seven months' investigation, the USTR finally released the Section 301 report $^{62}$ with unilateral findings on March 22, 2018. On the same day, President Trump announced "his decisions on the actions the Administration [will]

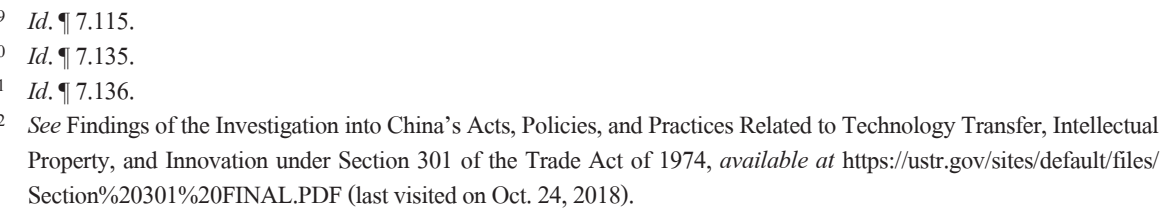
Property, and Innovation under Section 301 of the Trade Act of 1974, available at https://ustr.gov/sites/default/files/ Section\%20301\%20FINAL.PDF (last visited on Oct. 24, 2018). 
take in response to China's unfair trade practices covered in the USTR Section 301 investigation of China's Acts, Policies, and Practices Related to Technology Transfer, Intellectual Property, and Innovation." ${ }^{63}$ In this report, President Trump directed his Administration to take a range of legal actions. Two of three actions listed below are especially noteworthy in that they constitute an unprecedentedly unusual combination.

WTO Case: At the direction of the President, USTR will confront China's discriminatory technology licensing practices through a World Trade Organization (WTO) dispute.

25 Percent Ad Valorem Duties: USTR will propose additional tariffs on certain products of China, with an annual trade value commensurate with the harm caused to the U.S. economy resulting from China's unfair policies. The proposed product list subject to the tariffs will include aerospace, information and communication technology, and machinery. ${ }^{64}$

Then, on March 23, 2018, the USTR formally filed a request ${ }^{65}$ for consultations with China at the WTO. Since then, America has initiated its two-pronged approach regarding the IP-related trade conflicts with China. One is to sue China within the WTO dispute settlement mechanism and the other is to continue formulating the proposed tariff sanctions within the Section 301 framework. Subsequently, the USTR held public hearings on May 15-17, 2018 regarding the proposed tariffs on approximately USD 50 billion worth of Chinese imports. ${ }^{66}$ Despite a comprehensive three-day public hearing with more than 120 witnesses from a variety of industries both in the US and China, ${ }^{67}$ the implementation and further escalation of these tarrifs

63 USTR, President Trump Announces Strong Actions to Address China's Unfair Trade, Mar. 22, 2018, available at https://ustr.gov/about-us/policy-offices/press-office/press-releases/2018/march/president-trump-announces-strong (last visited on Oct. 24, 2018).

64 Id.

65 USTR, Following President Trump's Section 301 Decisions, USTR Launches New WTO Challenge against China, Mar. 23, 2018, available at https://ustr.gov/about-us/policy-offices/press-office/press-releases/2018/march/followingpresident-trump\%E2\%80\%99s-section. See also DS542: China - Certain Measures Concerning the Protection of Intellectual Property Rights, available at https://www.wto.org/english/tratop_e/dispu_e/cases_e/ds542_e.htm (all last visited on Oct. 24, 2018).

66 USTR, Public Hearings on the Proposed Section 301 Tariffs, May 14, 2018, available at https://ustr.gov/about-us/policyoffices/press-office/press-releases/2018/may/public-hearings-proposed-section-301 (last visited on Oct. 24, 2018).

67 See More than 120 witnesses scheduled for three-day Section 301 hearing, May 14, 2018, available at https:// insidetrade.com/trade/more-120-witnesses-scheduled-three-day-section-301-hearing (last visited on Oct. 24, 2018). 
seems inevitable. Because a series of direct bilateral high-level talks ${ }^{68}$ from May to June 2018 did not achieve the goal of peaceful settlement of all the existing trade disputes, the USTR finally released a list of products imported from China which would be subjected to new tariffs. ${ }^{69}$ As of October 2018, there is no sign of a peaceful settlement, on the contrary, further deterioration in relations seems much more likely. ${ }^{70}$

Obviously, the US intended to take 'legal' actions against China through a comprehensive strategy containing two main components. One is to propose unilateral sanctions such as imposing additional tariffs and the other is a WTO complaint challenging certain Chinese measures. But can this multilaterally compliant WTO complaint offset the violation of international law in terms of WTO discipline?

\section{B. Legal Analysis of the Unilateralism under the Current Combination of American Tactics}

Following the analytical logic of the adjudication made by the Panel of DS152, ${ }^{71}$ such a combination actually violates WTO law. The reasons are as follows. The unilateral initiation of this Section 301 investigation per se is completely inconsistent with its commitments particularly made in the SAA. Accordingly, the conclusion made by the Panel would be that such an approach is generally untenable under these specific circumstances. Therefore, America has violated Article 23 of DSU.

68 See, e.g., White House: Top Chinese economic adviser heading to DC next week to continue trade talks, May 7, 2018, available at https://insidetrade.com/trade/white-house-top-chinese-economic-adviser-heading-dc-next-week-continuetrade-talks; Readout of Discussions between Administration Officials and a Delegation from China Regarding the Trade Relationship between the United States and China, June 4, 2018, available at https://www.whitehouse.gov/ briefings-statements/readout-discussions-administration-officials-delegation-china-regarding-trade-relationship-unitedstates-china; China 'surprised' by Trump's tariff reversal, says it violates joint agreement, May 29, 2018, available at https://chinatradeextra.com/daily-news/china- $\% \mathrm{E} 2 \% 80 \% 98$ surprised $\% \mathrm{E} 2 \% 80 \% 99$-trump $\% \mathrm{E} 2 \% 80 \% 99$ s-tariffreversal-says-it-violates-joint-agreement (all last visited on Oct. 24, 2018).

69 See USTR Issues Tariffs on Chinese Products in Response to Unfair Trade Practices, June 15, 2018, available at https://ustr.gov/about-us/policy-offices/press-office/press-releases/2018/june/ustr-issues-tariffs-chinese-products (last visited on Oct. 24, 2018).

70 J. Cox, Trump says he's 'ready' to put tariffs on all $\$ 505$ billion of Chinese goods imported to the US, CNBC NEwS, July 20, 2018, available at https://www.cnbc.com/2018/07/19/trump-says-hes-ready-to-put-tariffs-on-all-505-billionof-chinese-html (last visited on Oct. 24, 2018).

71 The conclusion made by the panel of DS152 incurred some doubts or even criticism by commentators. For example, "While the United States--Section301 Panel Report is politically astute, its legal underpinnings are flawed in some respects and its policy implications for the future of the WTO Dispute Settlement Body (DSB) generate serious concerns. Moreover, the Panel ruling explicitly left many important legal questions unresolved, including consistency with the WTO obligations of specific actions taken by the USTR under Section 301 procedures." See Seung Wha Chang, Taming Unilateralism under the Multilateral Trading System: Unfinished Job in the WTO Panel Ruling on U.S. Sections 301-310 of the Trade Act of 1974, 31 L. \& PoL'y INT'L Bus. 1156 (2000). 
As listed above, in the SAA, the US explicitly promised: "The Trade Representative will base any section 301 determination that there has been a violation or denial of U.S. rights under the relevant agreement on the panel or Appellate Body findings adopted by the DSB." 72 In accordance with the inherent logical sequence contained in this specific commitment, the conditional legality of the overall Section 301 enforcement mechanism will be essentially ensured. Consequently, the US shall base the 2017 Section 301 determination on the subsequent Panel or Appellate Body findings in DS542, ${ }^{73}$ if the procedure of this case were to go further into the Panel or Appellate Body adjudicative stage. In sharp contrast, however, the US actually reversed this promised legitimate procedural sequence under the WTO dispute settlement. Instead, with questionable legality, it unilaterally made one-sided findings with threats and even actual imposition of additional tariffs. Once such proposed additional tariffs are actually enforced, the US would also be in violation of Articles I:1 and II:1 (a) and (b) of the GATT 1994 in addition to Article 23 of the DSU. ${ }^{74}$

Furthermore, even if the US should attempt to defend its reuse of Section 301 by virtue of the 'four corners' defense, ${ }^{75}$ such a combination could not be adequately justified yet. In brief, "the 'four corners' defense contains at least three separate categories: the uncovered party, the uncovered issue, and the uncovered practice. In other words, if a unilateral action targets a party that has not acceded to the WTO, an issue not covered by a WTO Agreement, or a trade practice that is not justiciable by the WTO, Article 23 will not then apply. Without Article 23 in the picture, the US may act unilaterally and unleash the full force of Section 301."76

First, as China is a member of the WTO, the 'uncovered party' criterion does not apply. Secondly, just as indicated in the IP-related subject matters in the Section 301 investigation and the subsequent WTO complaint, China-Certain Measures concerning the Protection of Intellectual Property Rights (DS542), the issues concerning protection of

\footnotetext{
Supra note 58

3 Supra note 65.

74 "On 4 April 2018, China requested consultations with the United States concerning certain tariff measures on Chinese goods which would allegedly be implemented through Section 301-310 of the US Trade Act of 1974." See DS543: United States-Tariff Measures on Certain Goods from China, available at https:/www.wto.org/english/tratop_e/dispu_ e/cases_e/ds543_e.htm (last visited on Oct. 24, 2018). For some representative views particularly expressing concerns about the conflicts between Section 301 and GATT (or DSU, etc.), see Sec. II(B) of this paper.

75 See Message from the President of the United States Transmitting the Uruguay Round Trade Agreements, Texts of Agreements Implementing Bill, Statement of Administrative Action and Required Supporting Statements, H.R. Doc. No. 316, 103d Cong., 2d Sess. 1 (1994), at 1035-36. For details, see J. Silverman, Multilateral Resolution over Unilateral Retaliation: Adjudicating the Use of Section 301 before the WTO, 17 U. PA. J. INT'L Econ. L. 233 (n. 198) (1996).
} 
IP rights are squarely within the scope of TRIPs, a WTO covered agreement so that the 'uncovered issue' criterion does not apply in this specific context, either. Thirdly, according to the criterion of the 'uncovered practice' the measures at issue with regard to IP protection on the surface are not in line with it, either. Consequently, even the basically reasonable 'four corners' defense can neither apply nor justify the legally impermissible unilateralism of the 2017 Section 301 investigation and the corresponding findings.

Therefore, even if the core aim of this 2017 Section 301 investigation was to obtain more negotiating leverage "through feints and threats," investigation conducted by the US should be prohibited based on the above-analysis in the context of WTO case law. In addition, such a subsequent WTO complaint would not offset the illegality of the unilaterally-initiated Section 301 investigation.

\section{The Potential Negative Impacts for the US in the World Trade Arena}

The US should have the legal right to take actions against any WTO members concerning any WTO covered agreements. However, it should only take such legal actions in consistent with international legal rules pertinent to the WTO related issues covered by certain agreements, such as TRIPs. Such unilateral actions would, at least potentially, have negative impact on its own interests, in addition to the severe negative impacts on the development of international trade rules.

First, such a unilateral action will definitely incur reputational costs. ${ }^{78}$ This outcome has been demonstrated by many scholars and trading partners. They cast doubt on the legality of the use of Section 301 and numerous negative statements have been issued concerning the obvious use of power-oriented Section 301 enforcement mechanism. A noticeable example is the WTO dispute (DS152).$^{79}$ Therefore, both previous and potential reputational costs ahead are apparent and understandable.

Secondly, such a unilateral action against China could potentially trigger

77 "More than any other U.S. trade law, section 301 works through feints and threats, rather than through formal legal processes." See Fisher et al., supra note 33, at 578. "The U.S. Government may be able to use the 'threat' of a 301 petition as leverage to get a foreign government to change a practice which the U.S. Government itself has not been successful in getting removed through purely diplomatic means." See S. Coffield, Using Section 301 of the Trade Act of 1974 as a Response to Foreign Government Trade Actions: When, Why, and How, 6 N.C.J. INT'L L. \& Com. REG. 390 (1980).

78 "Retaliation, if perceived as unjustified, carries a reputational cost. Every action in the international arena either contributes to or detracts from a positive reputation. If the United States retaliates erratically based on its own subjective notions of fair play, its reputation as a reliable trading partner and an economic world leader will falter." See Silverman, supra note 75 , at 286 .

79 The United States was clearly aware of such, at least potential, reputation costs. For instance, "In its submissions, the US itself volunteered that Sections 301-310 are an unpopular piece of legislation. In addition to the EC, twelve of the sixteen third parties expressed highly critical views of this legislation." See DS152, supra note 1, $₫ 7.11$ 
unanticipated harm on the US own interests in terms of technological costs. Certainly, this would not be a desirable outcome for the US itself. For instance, according to some recent research from a renowned think tank, such tariffs to be imposed would "harm US technology competitiveness" and instead hit non-Chinese multinational corporations operating in China ... disadvantaging American producers and harming US allies operating in the region., ${ }^{, .1}$

Thirdly, this kind of unilateral investigation would potentially result in undesirable US domestic economic loss in terms of sacrificing certain private sector interests. ${ }^{82}$ For instance, as analyzed in an earlier research article, "in order to enhance presidential discretion, the statute provides no congressional or judicial review of presidential decisions under the statute; the President is free to sacrifice the private interests at stake in an investigation in order to pursue national political, economic, or legal goals. ${ }^{~} 83$ To achieve certain political or economic goals at the cost of innocent private interests would not only be unfair to such private sector entities, but could also trigger potential domestic economic complications. Therefore, America may harms itself more than its perceived opponent. China thrived in the early 1990's when severely disadvantaged and the country's resilience is not to be underestimated. ${ }^{84}$

80 M. Lovely \& Liang Yang, Trump Tariffs Primarily Hit Multinational Supply Chains, Harm US Technology Competitiveness, PIIE Policy Brief 18-12, May 2018, available at https://piie.com/publications/policy-briefs/trumptariffs-primarily-hit-multinational-supply-chains-harm-us (last visited on Oct. 24, 2018).

81 M. Lovely \& Liang Yang, Revised Tariffs Against China Hit Non-Chinese Supply Chains Even Harder, PIIE Chart, June 18, 2018, available at https:/piie.com/research/piie-charts/revised-tariffs-against-china-hit-non-chinese-supplychains-even-harder (last visited on Oct. 24, 2018).

82 See Florida lawmaker, citing spiny lobster trade, urges Lighthizer to reconsider 301 tariffs on China, CHINA TRADE ExtRA, July 17, 2018, available at https:/chinatradeextra.com/sites/chinatradeextra.com/files/documents/2018/ jul/wto2018_0327.pdf. "So any slowdown in China trade flow could bring layoffs, Cordero said. It would also cut into the roughly $\$ 320$ billion in local and state tax revenues generated every year by trade flows in ports across the country, he said." See J. Schoen \& E. Newburger, US ports are on the front line of Trump's trade war - and they're bracing for higher China tariffs, CNBC NEws, July 28, 2018, available at https://www.cnbc.com/2018/07/27/us-portsbrace-for-higher-tariffs-from-china-in-trump-trade-war.html. Thus far, additional 301 tariffs have been questioned extensively even in the US. See also Lawmakers, industry groups question additional 301 tariffs, available at https:/ chinatradeextra.com/daily-news/lawmakers-industry-groups-question-additional-301-tariffs. As publicly pointed out by MS. Susan Schwab, a former USTR, "Tariffs ... are self-imposed wounds. And anyone who pretends that U.S. imposition of tariffs isn't hurting the U.S. economy is fooling themselves." See A Conversation with Six Former USTRs, CSIS, Sept. 17, 2018, available at https:/www.csis.org/analysis/conversation-six-former-ustrs (all last visited on Oct. 24, 2018).

83 Hansen, supra note 13, at 1128. Similarly, "a sanction is basically self-defeating in that the withdrawal of concessions simply means that a party to GATT will have to purchase on the world market at a higher price." See J. Jackson, GATT as an instrument for the settlement of trade disputes, 61 AM. Soc'Y InT'L L. Proc. 152 (1967).

84 P.Yu, From Pirates to Partners: Protecting Intellectual Property in China in the Twenty-First Century, 50 AM. U. L. Rev. 133-4 (2001). See also U.S., China tangle over Section 301 tariffs at WTO General Council, China Trade ExTRA, May 10, 2018, available at https://chinatradeextra.com/daily-news/us-china-tangle-over-section-301-tariffs-wtogeneral-council (last visited on Oct. 24, 2018). 
Fourthly, such legally impermissible unilateral investigations would likely bring about greater retaliation. ${ }^{85}$ This has been sufficiently observed and analyzed in many earlier articles. ${ }^{86}$ Moreover, the undesirable escalation of economic losses, not solely limited to the trade domain, could almost certainly lead to a more severe economic upheaval. A possible, though unwelcome tit for tat escalation could continue indefinitely leading to huge economic losses on both sides.

This leads on to the fourth point. Such a globally undesirable escalation would lead to negative influences for the whole world. As analyzed, "trade sanctions can have spillover effects on other US objectives and, if abused, a corrosive effect on the international trading system itself." ${ }^{87}$ Currently, such related concerns are also explicitly expressed by the WTO. ${ }^{8}$ Furthermore, recently, more WTO members have been striving to "voice concerns over rising trade tensions." " Thus, at least potentially, such undesirable spillover effects on both sides and on the global trade should not be neglected.

85 See China announces retaliatory tariffs, mirroring U.S. in escalating trade spat, China Trade Extra, June 15, 2018, available at $\mathrm{https}$ //chinatradeextra.com/daily-news/china-announces-retaliatory-tariffs-mirroring-us-escalatingtrade-spat. In addition, China even released a national level formal white paper on September 24, 2018, refuting U.S. allegations and showing an unyielding stance. See China releases white paper on facts and its position on trade friction with U.S., PeOPLE's DAILY, Sept. 24, 2018, available at http://en.people.cn/n3/2018/0924/c90000-9503026.html (all last visited on Oct. 24, 2018).

86 Some views in different articles are listed herein. "It would be naive to suppose that the United States can bully foreign countries into changing their systems without increasing the likelihood of counter-retaliations..." See Phillips, supra note 44, at 524-5. "Like any power-oriented system, section 301 can generate a high degree of unpredictability, particularly if the cases frequently lead to U.S. retaliation and foreign counter-retaliation. ... When the United States imposes sanctions on foreign goods, foreign governments have not infrequently struck back by imposing reciprocal sanctions on American goods or investments." See Maruyama, supra note 33, at 401. "Too often threatening a trading partner could provoke that government to stonewall or retaliate rather than to satisfy American demands, thereby closing rather than opening markets around the world." See Bello et al., supra note 37, at 13. "Section 301 action may provoke counterretaliation against the United States. If misguidedly applied, threats of unilateral retaliation could result in a trade war, especially if used against other economic superpowers." See Silverman, supra note 73, at 287.

87 Maruyama, supra note 33, at 401.

88 E.g., a deep concern was stated: "In light of recent trade policy developments they must now be considered to be tilted to the downside. Increased use of restrictive trade policy measures and the uncertainty they bring to businesses and consumers could produce cycles of retaliation that would weigh heavily on global trade and output." See Strong trade growth in 2018 rests on policy choices, WTO Press Release, Apr. 12, 2018, available at https://www.wto.org/ english/news_e/pres18_e/pr820_e.htm. For the latest deep concern, see Azevêdo 'very concerned' U.S.-China trade conflict will extend beyond tariffs, World Trade Online, Sept. 20, 2018, available at https://insidetrade.com/trade/ azev $\%$ C3\%AAdo- $\%$ E2\%80\%98very-concerned $\%$ E2\%80\%99-us-china-trade-conflict-will-extend-beyond-tariffs (all last visited on Oct. 24, 2018).

89 "Forty-one members of the World Trade Organization issued a joint statement on 8 May expressing concerns over rising trade tensions and risks of escalating protectionism. The statement, delivered to a meeting of the WTO's General Council, calls on governments to resolve their differences through dialogue and cooperation, including through the WTO." See Members voice concerns over rising trade tensions, underline support for WTO, WTO News, May 29, 2018, available at https://www.wto.org/english/news_e/news18_e/gc_07may18_e.htm (last visited on Oct. 24, 2018). 


\section{Conclusion}

Section 301 investigation is unilaterally threatening to impose or actually imposing additional tariffs against China. It has clearly run counter to the explicit commitments made in the SAA. Consequently, based on the panel's additional emphasis, ${ }^{90}$ the conditional legality confirmed by the Panel of DS152 case should be untenable in this specific context. Furthermore, even the multilaterally compliant WTO case cannot offset the violation of international law in terms of the WTO discipline. Thus, it is suggested that the US cease using Section 301 investigation against the WTO members arising from trade disputes under the WTO covered agreements, as it did between 2001 and 2017.

By reutilizing this globally aversive tool, the US could potentially portray itself to be an unreliable trade partner which would unavoidably incur severe reputational costs and other potential harms to itself. Furthermore, this legally impermissible unilateralism would, to a certain extent, undermine or even undo the many benefits of international rule of law which have been in use and beneficial for more than twenty years in the world trade arena under the WTO guidance. Accordingly, for the sake of its own interests as well as other benefits related to the world trade and even global peace, ${ }^{91}$ the US should be sufficiently prudent in invoking such a sensitive and controversial tool especially against the WTO members concerning issues within the scope of the WTO covered agreements, such as TRIPs. Otherwise, Section 301 investigation could, conceivably, turn a gradually-established rule-based world trading system which has been evolving since the end of World War II into a globally undesirable power-based world trading system. If so, the operating uncertainties of the overall world trading system would reach a level beyond reasonable prediction, introducing the most unwelcome element into global economics-'uncertainty.' History repeatedly shows that markets abhor uncertainty, but that is precisely what America's current policy is creating. It will thus potentially harm every participant in the world trading system and the world trading system per se. All in all, only mutually beneficial solutions are most desirable, effective and sustainable for both China and the US.

90 "Should the undertakings articulated in the SAA and confirmed and amplified by the US to this Panel be repudiated or in any other way removed by the US Administration or another branch of the US Government, this finding of conformity would no longer be warranted." See supra note 1, ๆ 7.136.

91 "A slide toward protectionism would also undermine the institutions that the United States has long worked to support, such as the World Trade Organization (WTO), which have made meaningful contributions to global peace and prosperity." See D. Irwin, The False Promise of Protectionism: Why Trump's Trade Policy Could Backfire, 96 FoREIGN AFr. 45 (2017). 
